\title{
Structural geology of the Huldra Field, northern North Sea—a major tilted fault block at the eastern edge of the Horda Platform
}

\author{
Haakon Fossen ${ }^{\mathrm{a}, *}$, Jonny Hesthammer ${ }^{\mathrm{a}}$, Tord Erlend Skeie Johansen ${ }^{\mathrm{a}}$, Trond Olav Sygnabere ${ }^{\mathrm{b}}$ \\ ${ }^{\mathrm{a}}$ Department of Earth Sciences, University of Bergen, Allégt. 41, Bergen N-5007, Norway \\ bstatoil, N-5020 Bergen, Norway
}

Received 22 April 2003; received in revised form 19 July 2003; accepted 25 July 2003

\begin{abstract}
The Huldra fault block is a rotated major fault block on the east margin of the Viking Graben in the northern North Sea. Unlike the rest of the Horda Platform area, the Jurassic section in the Huldra fault block was rotated more than $20^{\circ}$ during slip on the listric Huldra fault, which forms a low-angle detachment beneath the Huldra fault block. The fault block is interpreted as resulting from marginal collapse of the Horda Platform after relief along the eastern margin of the Viking Graben built up in early parts of the middle to late Jurassic rifting history. The collapse resulted in NW directed transport of the Huldra fault block, consistent with a previously postulated change in extension direction from W-E to NW-SE toward the end of the Jurassic period. Minor faults within the Hulrda fault block are consistent with E-W extension and thus may have formed early during the late Jurassic rifting phase. Nevertheless, the crest (Huldra Field) seems surprisingly intact, considering its proximity to a major fault zone. Deformation bands studied from core material are non-cataclastic and concentrated in zones. Evidence for smearing along a cored fault surface indicates that minor subseismic faults may be sealing. Production data from the field indicate good communication between most wells, suggesting that the subseismic faults and deformation band zones that are present in the reservoir have relatively small influence on the flow of gas in the reservoir.
\end{abstract}

(C) 2003 Elsevier Ltd. All rights reserved.

Keywords: Huldra field; Structural geology; North sea; Marginal collapse

\section{Introduction}

Several large and smaller oil fields are located on the east side of the northern Viking Graben in the northern North Sea. These fields are located within the Horda Platform region, which was a fairly stable part of the Jurassic North Sea rift system as compared to the areas to the west (Viking Graben and Tampen area). The Huldra field is located on the western margin of the Horda Platform, close to the Viking Graben (Fig. 1). Its marginal location is associated with a substantial amount of block rotation and a relatively deep position as compared to other oil fields in this part of the North Sea. In particular, the middle Jurassic layers dip more steeply and faults dip more shallowly than those commonly observed on the Horda Platform, and the greater reservoir depth causes diagenetic effects that may turn out to be challenging in a production management perspective. In this

\footnotetext{
* Corresponding author. Tel.: +47-555-83520; fax: +47-555-89416.

E-mail address: haakon.fossen@geo.uib.no (H. Fossen).
}

article we present the results of a structural analysis of the Huldra area, based on 3D seismic data and available well data.

\section{Geologic setting}

The Huldra Field is situated on the west margin of the Horda Platform in the northern North Sea, where it occupies the crest of a large, rotated fault block (Figs. 1 and 2). Immediately to the east lies the Veslefrikk Field, farther east is the Troll Field and the larger Oseberg structure is located to the south of the Huldra Field.

\subsection{The Horda Platform}

The Horda Platform (Fig. 1) is the platform area on the eastern side of the northern North Sea, east of the Viking Graben. This area was extensively faulted during the Permo-Triassic phase of rifting (Fig. 2). Major faults with 


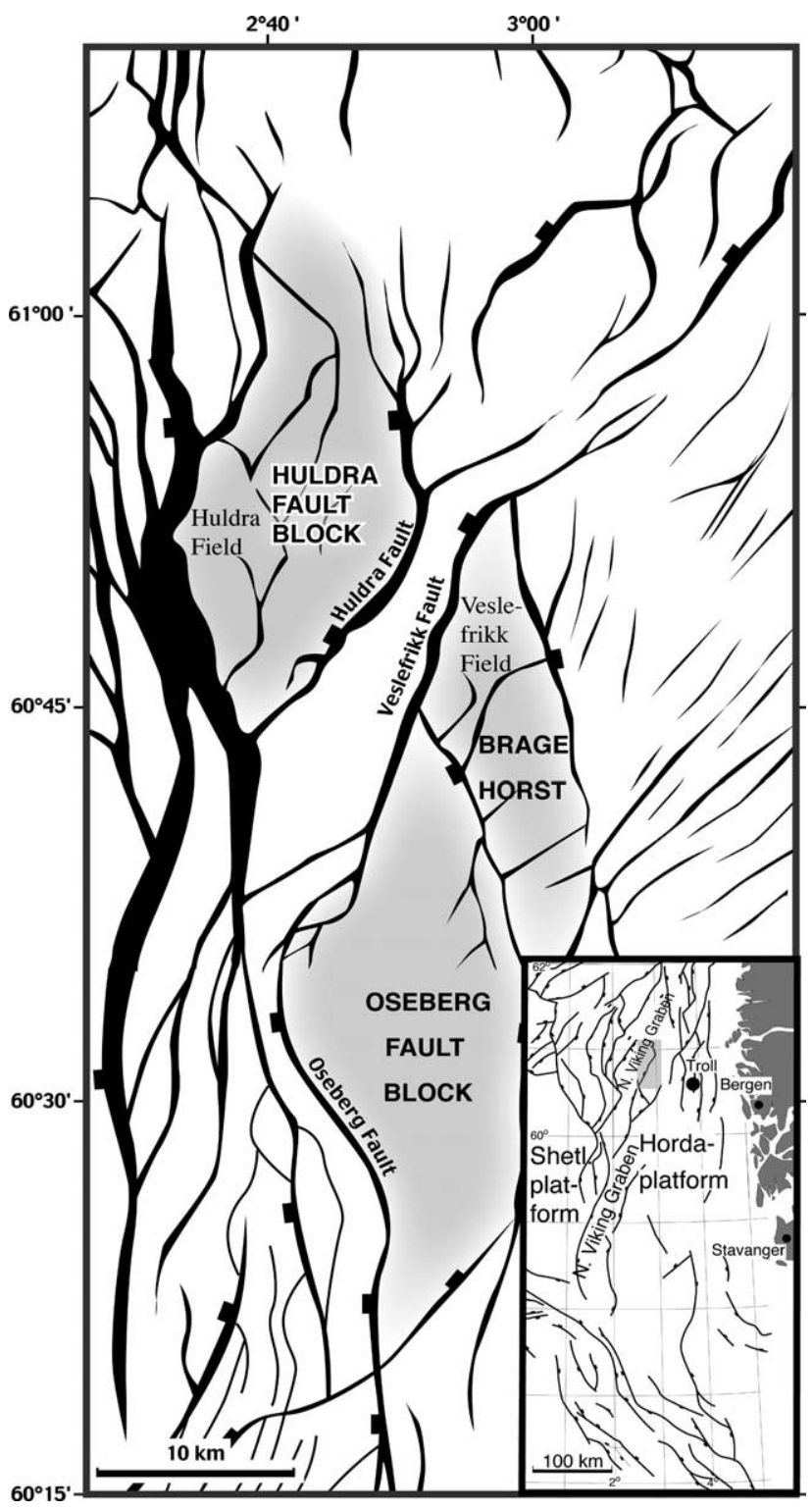

Fig. 1. Regional map of the western edge of the Horda Platform, showing the position of the Huldra Field in relation to the Veslefrikk Field/Brage horst and the Oseberg Fault Block.

up to several kilometers of throw formed during PermoTriassic extension. A series of half-grabens with E-dipping (?Permian-) Triassic strata resulted from this phase (Badley, Egeberg, \& Nipen, 1984; Færseth, Gabrielsen, \& Hurich,
1995; Gabrielsen, Steel, Idil, \& Kløvjan, 1990). Regional seismic lines (Fig. 2) reveal the half grabens that are covered by post-rift sediments of late Triassic-middle Jurassic age.

The late middle Jurassic-early Cretaceous phase of rifting, which caused extensive faulting in and west of the Viking Graben, only caused mild or moderate faulting and rejuvenation of Permo-Triassic faults in the Horda Platform and was associated with little extension (Roberts, Yielding, Kusznir, Walker, \& Dorn-Lopez, 1993). Hence, the Jurassic layers are sub-horizontal in large parts of the Horda Platform, contrasting the dipping lower Triassic strata (Fig. 2) (Gabrielsen et al., 1990; Steel \& Ryseth, 1990).

A marginal fault zone along the western side of the Horda Platform separates the platform from the Viking Graben. The Huldra Field is located along this marginal zone, aligned with the Oseberg fault block to the south and west of the Veslefrikk Field (Fig. 1).

\section{Huldra Field reservoir}

Exploration wells in the Huldra block are drilled through the Jurrasic sequence and well into the Statfjord Formation, although production wells are restricted to the middle Jurassic section. Well locations are restricted to the crestal (western) portion of the fault block, where the Huldra Field reservoir is made up of sand layers of the Brent Group. The Brent Group consists of porous sandstones interbedded with shales and subsidiary coal layers (Fig. 3). The upper part of the Brent Group is overlain by middle to upper Jurassic shales of the Heather Group. At the very crest of the structure, the contact between the Brent sands and the Heather shales is interpreted from well $\operatorname{logs}$ as an erosional unconformity. The base of the Heather Formation in well L1 (Fig. 4) is reported to be Lower Callovian or possibly older.

Reservoir porosity varies from low to medium and permeability is typically a few hundred $\mathrm{mD}$ in the reservoir sands. Diagenetic alteration during its burial history has reduced the permeability/porosity, which is lower than other Brent Group reservoirs in the North

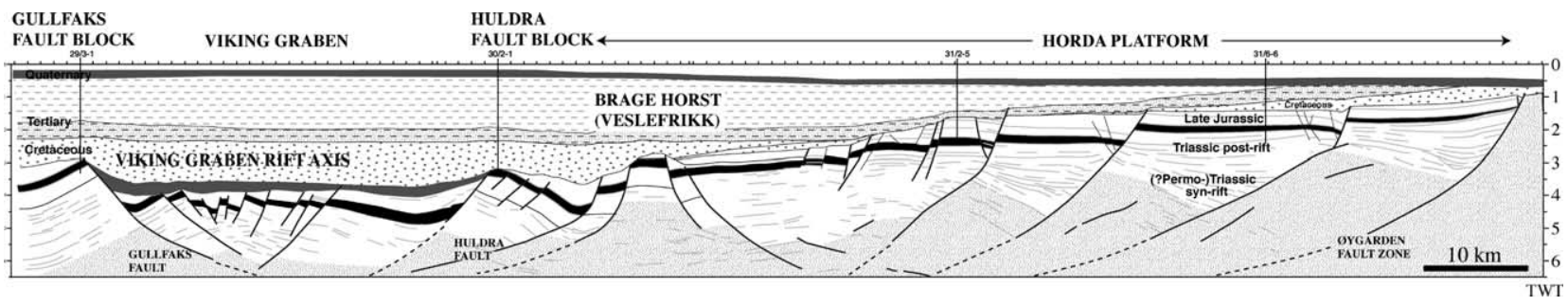

Fig. 2. Sketch based on E-W regional (2D) seismic line NVGT88-05, showing the setting of the Huldra Fault block in relation to the Viking Graben to the west and the Brage horst and Horda Platform to the east. Note Triassic half-grabens buried under sub-horizontal Jurassic strata on the Horda Platform. Basement interpretation is tentative. The lower-middle Jurassic section is shown in black. 


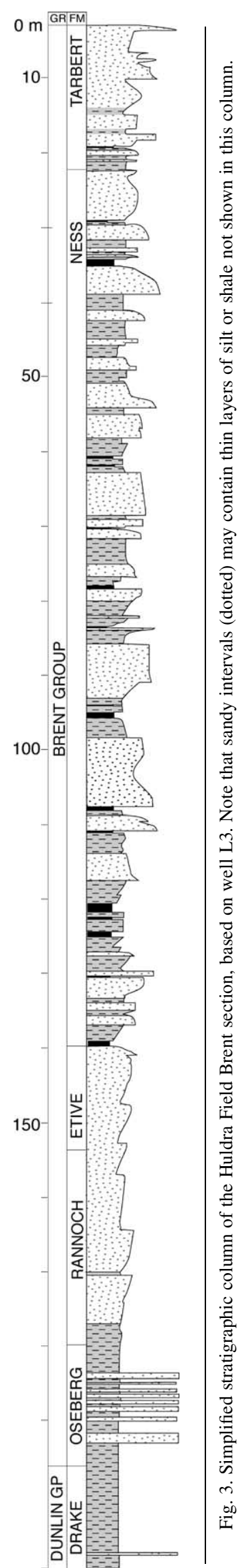

Sea province. Grain-contact dissolution of quartz and feldspar and precipitation of quartz and other minerals are the most important mesodiagenetic alteration processes that have reduced porosity and permeability. In addition, the sandstones may be affected by illitization.

The reservoir contains gas-condensate that is exploited through three vertical exploration wells and a dozen of production wells at the crest of the structure. Production and pressure data from the wells show good communication in the reservoir, in spite of its location close to a major fault zone. Stratigraphic barriers do however exist, giving rise to deeper contacts in upper Brent sands than in the lower Brent sands.

\subsection{General structure}

The Huldra Field is located at the crest of a rotated fault block, hereafter referred to as the Huldra fault block (Fig. 2). This block, up to $10 \mathrm{~km}$ wide, is bounded by two major faults. Each of the faults exhibits several kilometers of offset and belongs to what are sometimes referred to as first-order faults in the North Sea (e.g. Fossen \& Hesthammer, 1998a). The eastern (Huldra) fault shows up on various regional sections as a strongly listric structure (Fig. 2). This non-planar fault is also imaged on the 3D seismic data set from the Huldra fault block (Fig. 5). The fact that reflections appear to cross the interpreted fault surface reflection (Fig. 5) does, however, indicate that the migration is far from perfect and that the true position of the fault surface is somewhat uncertain even on seismic sections. In addition, no velocity information is available for the Triassic section, making the exact shape of the Huldra fault even more uncertain on depth sections.

The pre-late Jurassic layers in the Huldra fault block dip consistently $\sim 20^{\circ}$ to the east (Fig. 4). This contrasts to the sub-horizontal Jurassic layers in the Veslefrikk Field/Brage Horst and the Horda Platform in general (Fig. 2). Clearly, the Brage Horst is a stable, deep-rooted structure that separates two structural domains; the main Horda Platform area to the east and the marginal Huldra and Oseberg areas to the west (Figs. 1 and 2). These two structural domains show geometric differences as far as fault geometry and orientation of layering are concerned. Additionally, the Huldra fault marks the line at which Jurassic strain becomes significant. The Horda Platform shows minor Jurassic faulting activity only, whereas the Huldra fault block and its bounding faults are highly influenced by Jurassic deformation. The formation and rotation of the block are clearly of middle Jurassic-early Cretaceous age, as illustrated by the significant offset and rotation of the Jurassic strata (see below). 


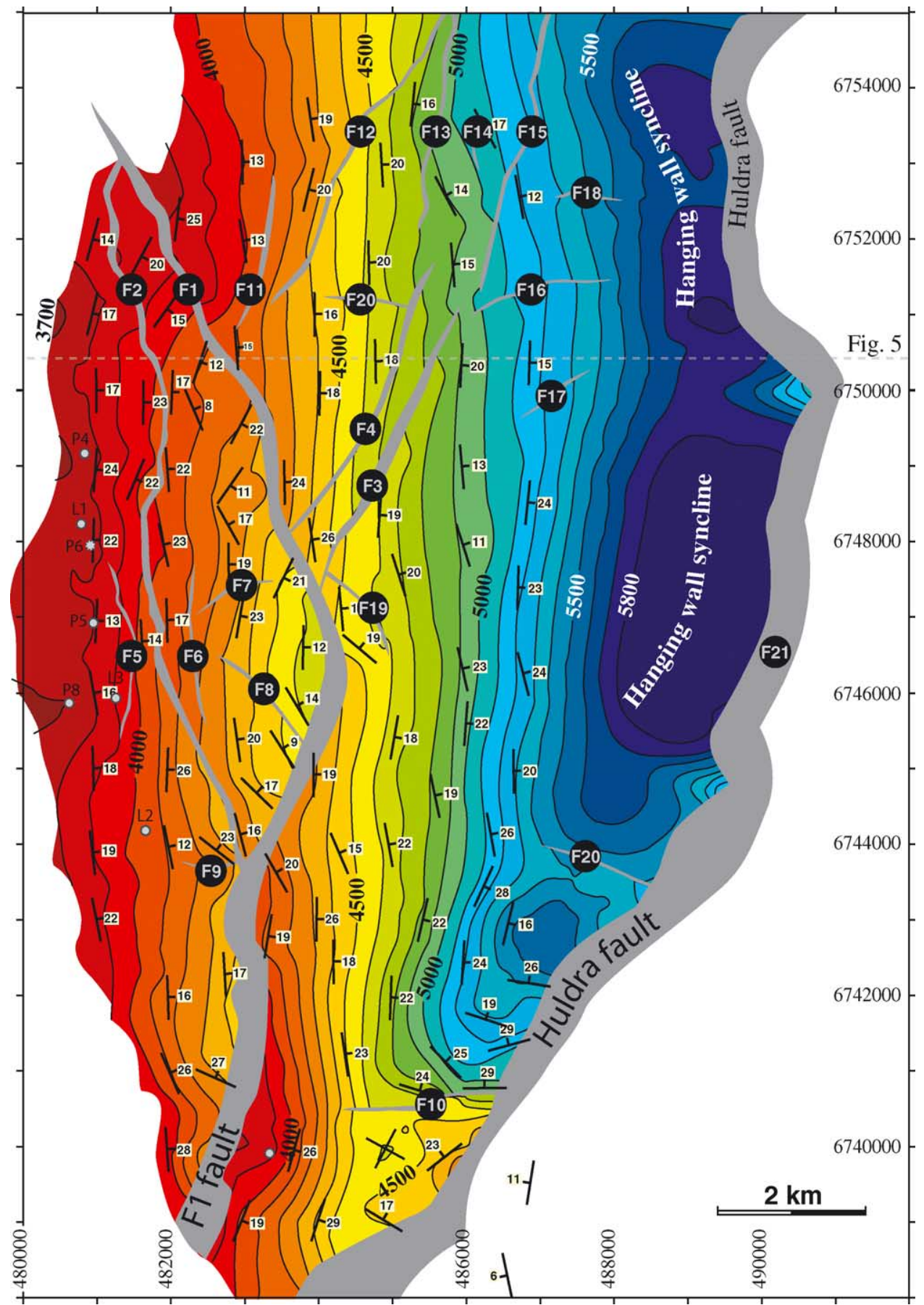

Fig. 4. Depth map of an intra Brent reflector. Calculated bedding orientations are shown and faults are numbered for reference.

\section{Structural description and analyses}

\subsection{Layering}

The consistently north-striking Huldra reservoir beds dip about $20^{\circ}$ to the east (Figs. 4 and 5). This consistent pattern is disturbed along the Huldra Fault, where a hanging wall syncline is developed (Fig. 4). The syncline has been accentuated by post-Jurassic differential compaction, as can be seen by sagged Cretaceous reflectors above the structure, but must have a tectonic origin. Most likely, it is related to irregularities (vertical dip changes or fault overlaps) along the fault surface that are not clearly imaged by the seismic data.

The overall $\mathrm{N}-\mathrm{S}$ trend of the layering (Figs. 5 and 6) in the Huldra fault block indicates block rotation about a N-S 

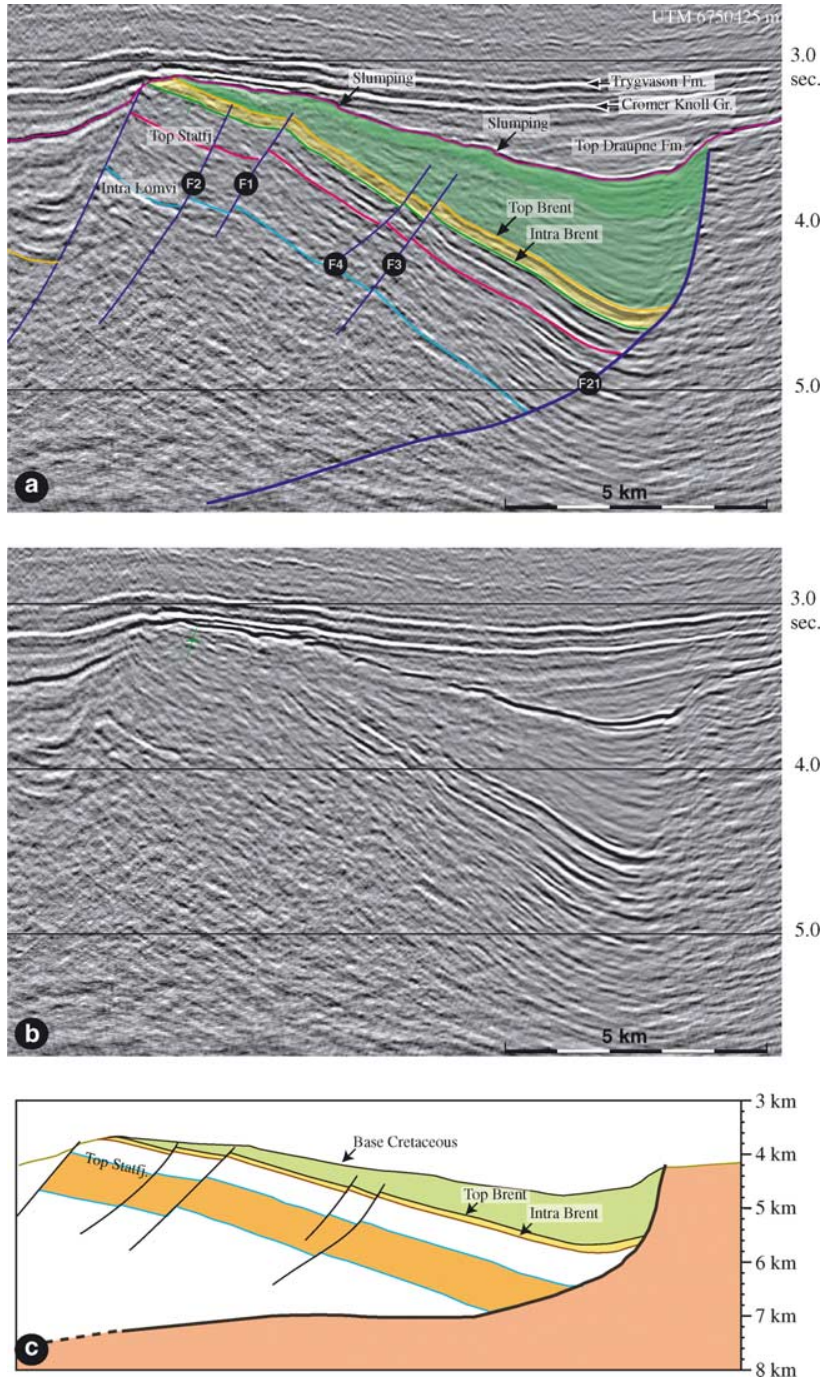

Fig. 5. Interpreted (a) and uninterpreted (b) seismic section (3D seismic line 1718) through the Huldra fault block. Note how the rotated layers within the block contrast to the more or less flat-lying reflectors in the hanging wall to the right. Depth converted line is shown (c). Depth conversion was made based on a linear velocity model down to the base Cretaceous reflector, and interval velocities calculated from well data. No well information is available for the pre-Statfjord Formation section, where a velocity slightly higher than the Statfjord Formation was used. See Fig. 4 for location.

axis. The amount of rotation is indicated by the average dip of the layering $\left(\sim 20^{\circ}\right)$, although internal subseismic or 'ductile' deformation and subsequent compaction may complicate the simple relationship between rotation and dip angle.

\subsection{Fault orientation and extension direction}

Many of the faults in the Huldra area show curved patterns in map view at reservoir level, around a general $\mathrm{N}-\mathrm{S}$ trend (335-035) (Fig. 4). The fault pattern is consistent with an approximately E-W extension direction. The extension direction has traditionally been considered as being W-E (Roberts, Yielding, \& Badley, 1990), but

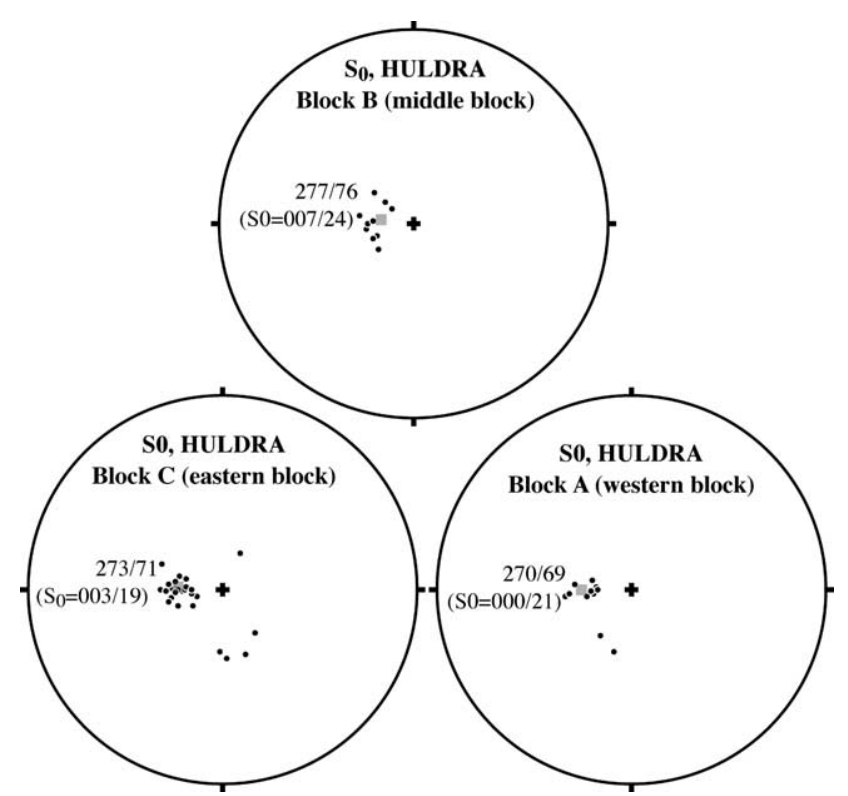

Fig. 6. Stereoplots (equal area) of poles to bedding (intra-Brent Formation), showing that bedding dips fairly consistently to the east by about $20^{\circ}$. The hanging wall fold in the easternmost part of the block is excluded.

Færseth, Knudsen, Liljedahl, Midbøe, \& Søderstrøm (1997) argued that the $\mathrm{N}-\mathrm{S}$ fault orientation is inherited from Permo-Triassic E-W extension, and that the NE-SW trending faults in and around the Horda Platform express a later change to a more NW-SE extension direction.

The Huldra Fault (Fig. 4) is oriented NE-SW to N-S in the study area. Any fault with cylindrical irregularity can only move easily along the axis of the curvature. Any other slip direction would require deformation of either the hanging wall, the footwall, or both (e.g. Fossen \& Hesthammer, 1998a), and would be both energetically and kinematically unfavorable. Hence, the slip or extension direction is indicated by the poles to the great circle constrained by the poles to the fault surface. The Huldra fault is not cylindrical due to its listric nature, but the same method can be applied if measurements are taken along the same depth level. Plotting the orientation of the fault along strike within the mapped area (Fig. 7) shows that the curved geometry is consistent with NW extension. This result was obtained from measurements at two different levels along the strike of the fault.

The orientations of the intra-Huldra fault block faults are generally different from those of the Huldra Fault. The largest of these faults (F1 in Fig. 4) is also the least planar, and thus constrains the extension direction quite well. The plot of F1 (Fig. 7) indicates E-W extension, for reasons outlined above (Fig. 7). From these data it seems that the main extension direction within the Huldra fault block is E$\mathrm{W}$, i.e. consistent with findings from the Gullfaks and Gullfaks Sør fields on the opposite side of the Viking Graben (Fossen \& Hesthammer, 1998a; Rouby, Fossen, \& Cobbold, 1996), but contrasting the many NE-SW trending faults in the Horda Platform to the east. Thus, the major 


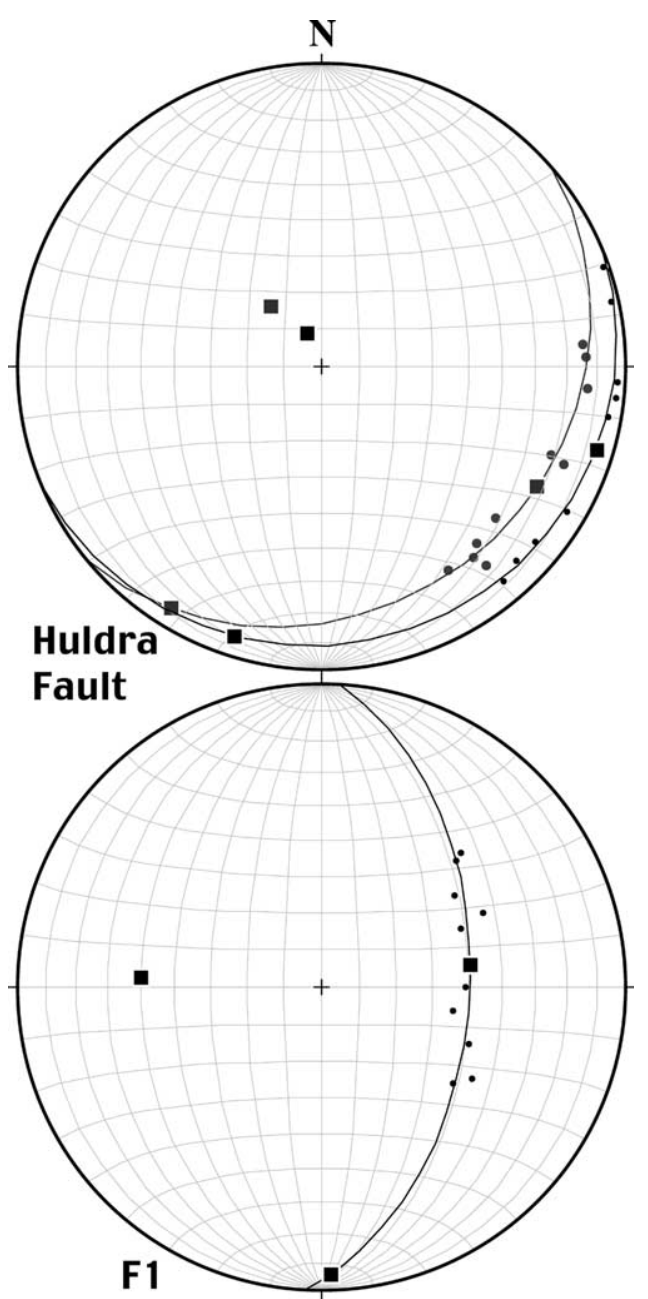

Fig. 7. Poles to Huldra Fault surface, measured at $2 \mathrm{~km}$ intervals along the fault at ca. $4800 \mathrm{~m}$ (black) and $6000 \mathrm{~m}$ (grey) depths. Poles at both levels plot along great circles that indicate a NW-plunging line of curvature. Bottom: plot of poles to F1, plotting along a great circle consistent with E-W extension. Black boxes indicate eigenvectors (Bingham analysis), of which one indicates the extension direction in each case (the pole to the great circle).

Huldra Fault appears to mark a spatial change in the late Jurassic-early Cretaceous extension direction.

\subsection{Fault segmentation}

A closer look at the larger faults reveals that they consist of a number of fairly straight segments, each with a slightly different strike orientation (Fig. 8). This pattern is quite common in the northern North Sea and other rift systems (e.g. on the Gullfaks Field; Fossen \& Hesthammer, 1998a) and, at least for the larger segments, must reflect real variations in fault orientation.

Abrupt strike variations or segmentation of faults are the likely result of linking of individual faults during growth. Growth by linkage is evident from experimental and field studies alike, and occurs in the vertical as well as the horizontal direction (Mansfield \& Cartwright, 2001;

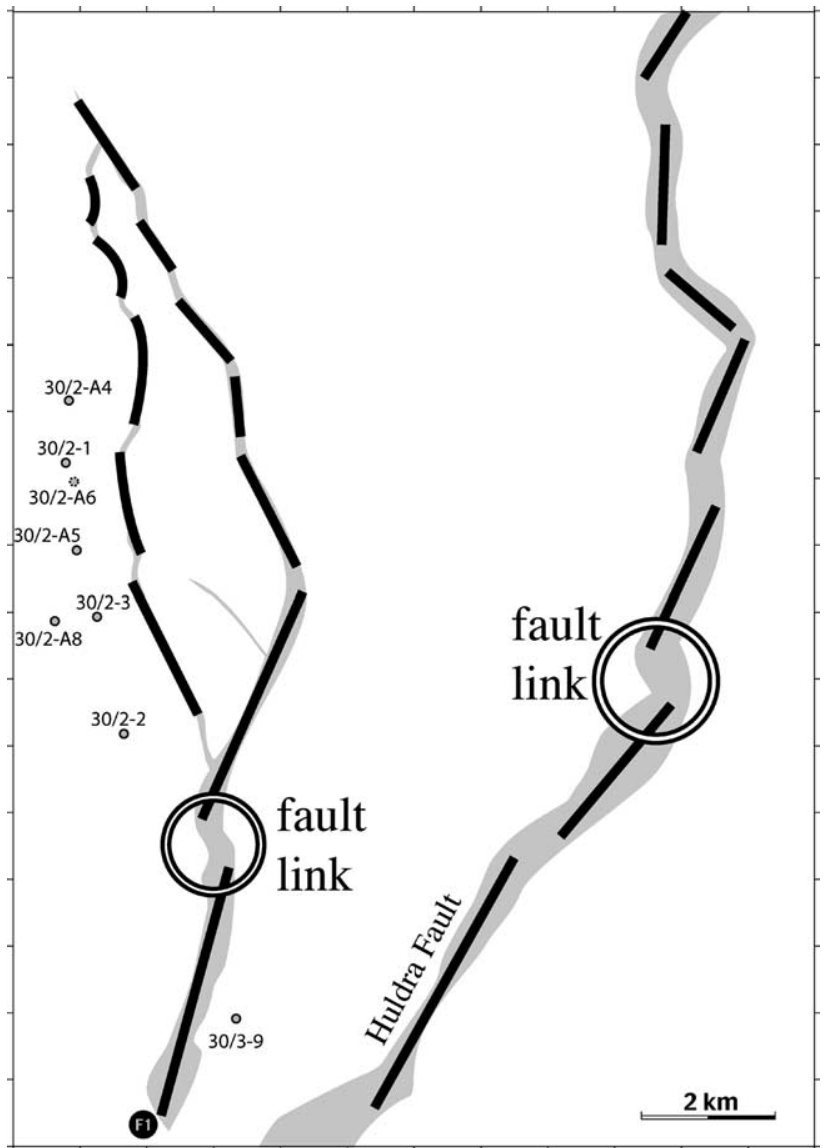

Fig. 8. Indication of how the F1 and the Huldra fault may be described as segmented. Segment links, such as those encircled, may represent fault links and breached relay structures.

Rykkelid \& Fossen, 2002; Scholtz, Dawers, Yu, \& Anders, 1993; Trudgill \& Cartwright, 1994). The fault bends (such as those encircled in Fig. 8) could therefore be areas of excessive damage created during linkage. The damage would be in the form of minor faults and deformation bands, and possible minor warping of the layering. The plaster experiment shown in Fig. 9 illustrates how multiple fault segments may grow into a single, larger-scale fault structure through the process of linking.

\subsection{Prediction of minor faults}

The low to moderate quality of the seismic data set, particularly in the western, hydrocarbon-bearing part of the block, makes the identification of faults with throw less than 30-50 m difficult. Faults below this range are expected to exist. As most sand units are around $10 \mathrm{~m}$ in thickness (maximum $30 \mathrm{~m}$, see Fig. 3), subseismic faults may give rise to juxtaposition seals as well as clay smear seals, in addition to the potential low-permeable properties of the fault deformation products themselves.

Seismic attribute maps have been used to image faults at the limit of seismic resolution, which may potentially show up as continuous lineaments on seismic attribute maps. 

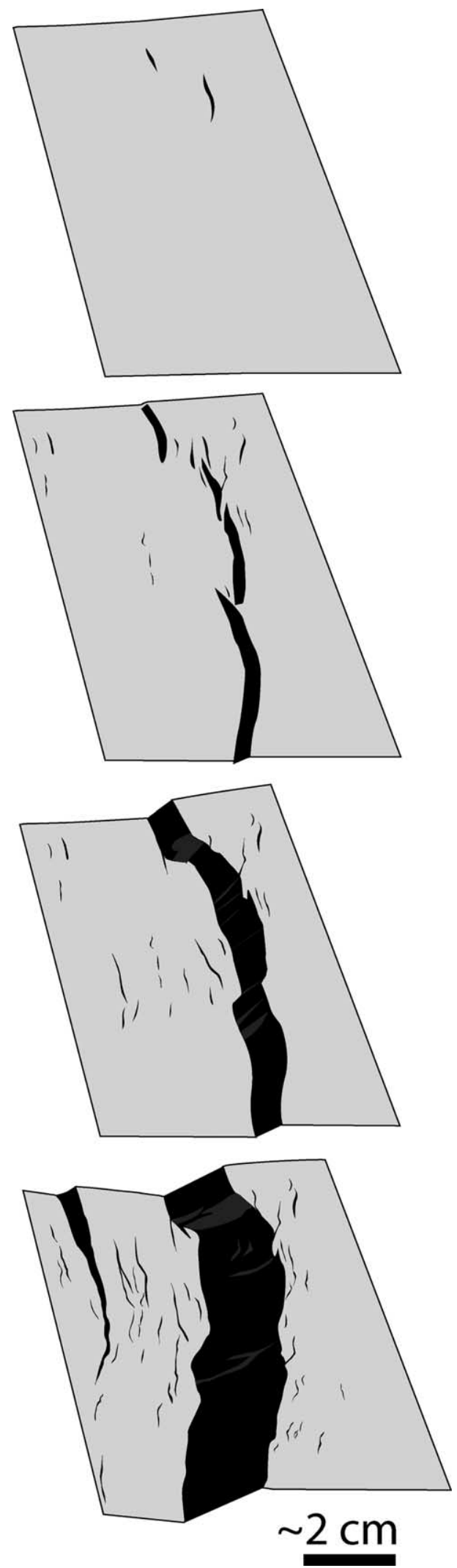

Fig. 9. Formation of a curved fault by growth and linking of three individual fault segments during horizontal stretching. Redrawn from previously unpublished plaster experiment (surface view). Note the similarity between the final fault trace of the major fault and the larger faults in the Huldra fault block.
As pointed out in previous studies from the Gullfaks area (Hesthammer, 1998; Hesthammer and Fossen, 1997a,b; Hesthammer, Landrø \& Fossen, 2001), great care must be exercised when interpreting curvilinear features from attribute maps as faults. Seismic noise generates features that may be impossible to distinguish from true faults without careful examination of additional data.

The reliability of the attribute analysis depends on the quality (strength) of the seismic reflection. We have chosen an intra Brent reflector, which is a strong reflector in the eastern part of the block, but considerably weakened in the crestal, hydrocarbon-filled part of the structure (Fig. 5). The attribute maps show curvilinear features that have been marked and displayed in Fig. 10. They fall into two main groups of approximately NW and NE trends. Some of these features coincide with faults already interpreted directly from seismic data (e.g. F3, F4, F16, F18; see Fig. 4) or are parallel to such fault orientations. The similarity in orientations opens the possibility that some of the attribute-based lineaments shown in Fig. 10 reflect real subseismic fault trends. On the other hand, dipping seismic noise is seen to weaken the reflections and set up curvi-linear features parallel to the strike of bedding, indicating that a large portion of the anomalies are seismic artifacts rather than true faults. Interference between low-angle multiples and bedding is another potential source of seismic artifacts on the attribute maps.

So far, production data indicate good communication between production wells at the crest of the Huldra fault block. The only barrier that can be seen from pressure data is located between P6 and P5 (Fig. 4). This indicates that the majority of the linear anomalies indicated in Fig. 10 are unreal or at least do not influence on the communication within the reservoir.

An additional argument against the presence of numerous subseismic faults in the reservoir is the fact that all the intra Brent depths from the wells fit a single plane within an error of few meters (error over $6 \mathrm{~km}$ is $22 \mathrm{~m}$ ). The plane dips $18^{\circ}$ to the east, consistent with the seismic interpretation in the well area and with dip information from the exploration wells. Although this information tells us that subseismic faults with throw large enough to offset individual sand sequences are uncommon in the reservoir, smaller deformation structures may still exist.

\subsection{Small-scale structures observed in cored sections}

None of the wells in the Huldra Field penetrate seismically resolvable faults. Nevertheless, a number of minor tectonic fractures (and a single minor fault) are identified in cores from well L1 and, to a lesser extent, wells L2 and L3. The fractures are shear bands of various kinds, depending mainly on the lithology in which they occur.

Deformation bands in which deformation has occurred by granular flow without cataclasis (disaggregation bands) are seen in Brent sandstones as diffuse bands with a slightly lighter color than the host rock (Fig. 11(a)). Because 


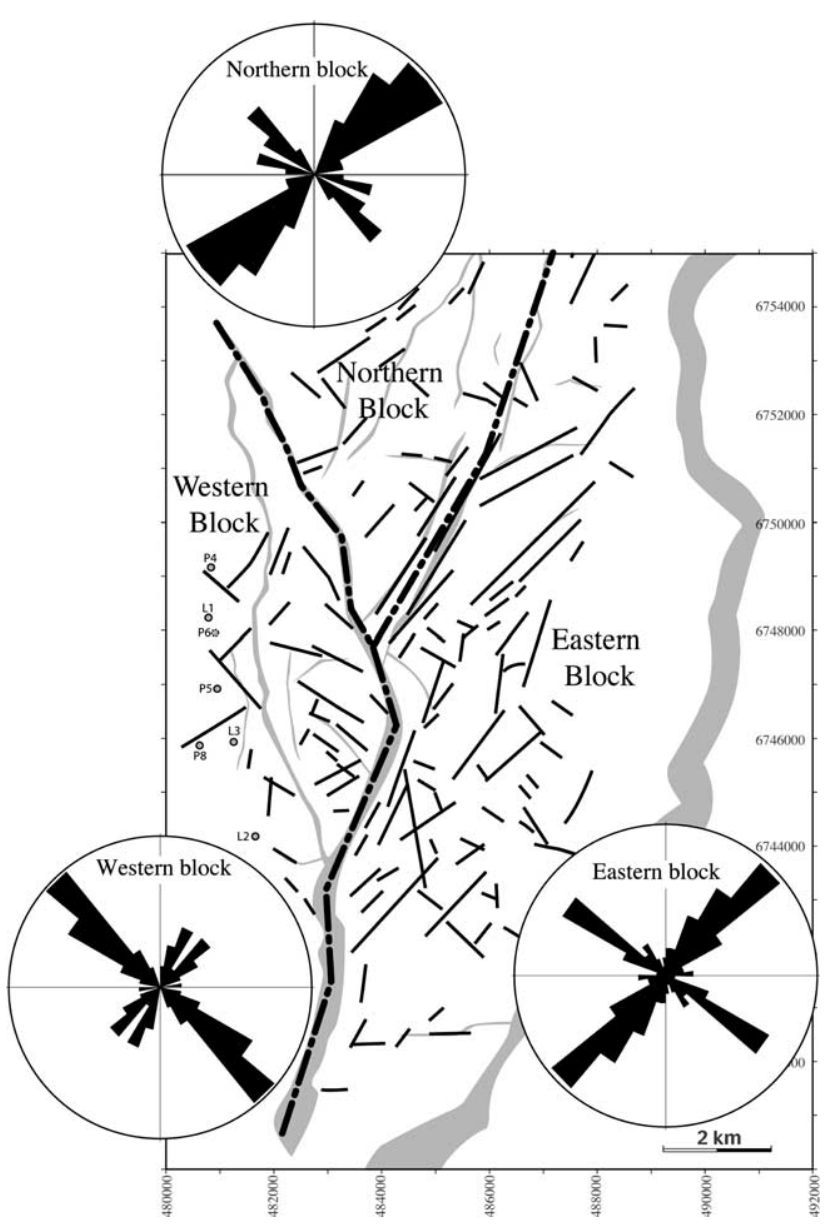

Fig. 10. Map and rose diagrams showing trends and positions of linear anomalies interpreted from seismic amplitude map (near the intra Brent horizon). It is possible that some of the lineaments from this 'aggressive' interpretation may represent small-scale faults, although the majority probably does not. See text for discussion.

the original grain size distribution is maintained, the limited compaction that may result from the grain reorganization can only cause minor or negligible reduction in permeability across the bands. Cataclasis has not been observed, because of the shallow burial depth during the late Jurassic-early Cretaceous deformation phase and the presence of phyllosilicates in the reservoir sands. However, post-tectonic quartz cementation has occurred in the bands. Although the amount of cementation seems minor in the limited number of samples examined, the possibility that cementation is more well developed elsewhere in the reservoir should be held open. This is particularly so because of the relatively deep burial of the field. In sandstone reservoirs located deeper than 2500$3000 \mathrm{~m}$, temperatures commonly have exceeded the critical temperatures for accelerated quartz dissolution and precipitation (ca. $120^{\circ}$ ) and illitization of kaolinite and K-feldspar (Hesthammer, Bjørkum, \& Watts, 2002). These processes lead to reduced porosity and permeability within the reservoir and the many shear bands found within damage zones around the many larger-scale faults. The shear bands are most affected by grain-to-grain quartz dissolution and
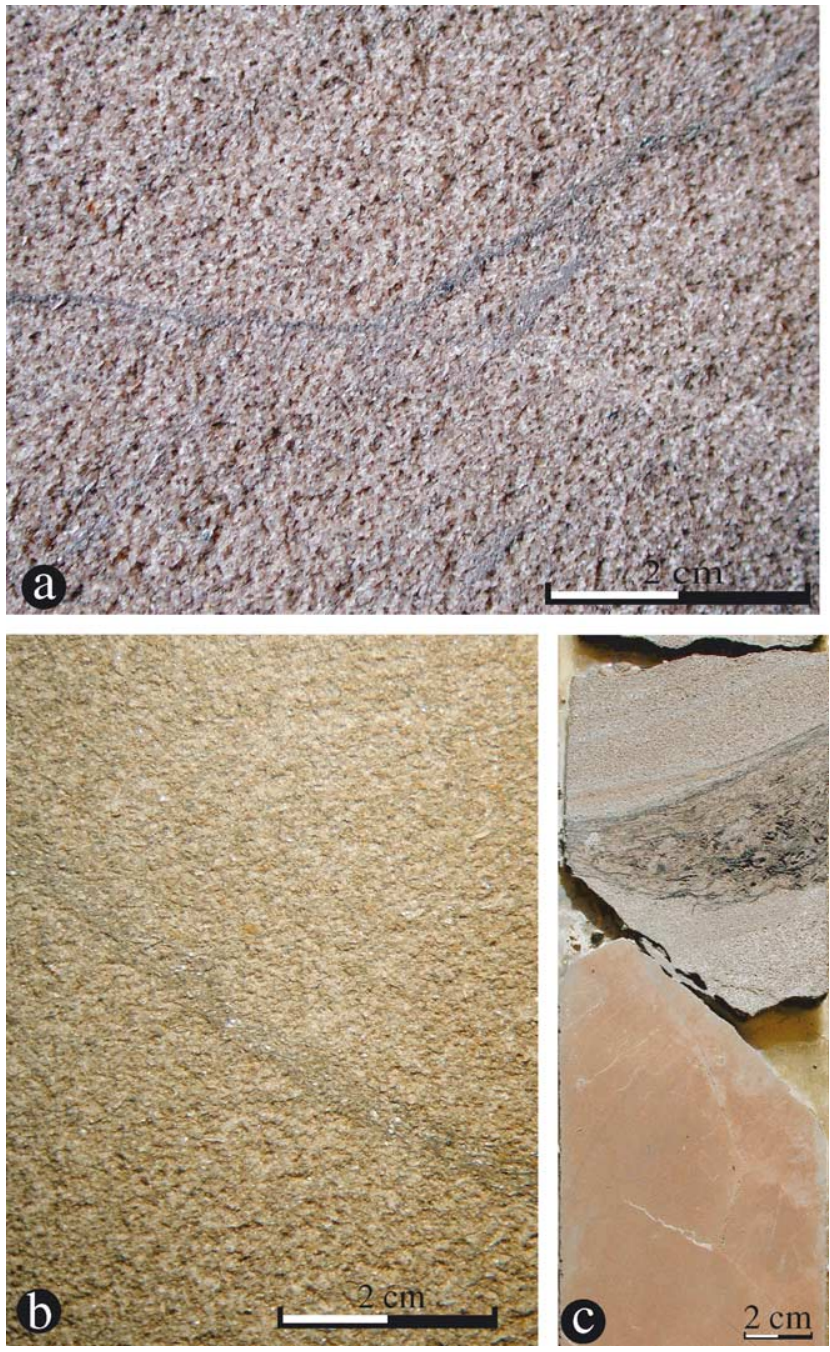

Fig. 11. (a) Deformation band from well L1. The band is a typical disaggregation band in the right part of the picture, changing to a phyllosilicate framework band in the left part of the picture. (b) Example of $\sim 1 \mathrm{~mm}$ thick phyllosilicate framework band from the Huldra Field. Note the aligned platy minerals giving the bands a dark appearance. Well L1. (c) Minor fault in well L3. Note drag in the hanging wall. Orientation analysis indicates that this fault has a southerly strike and dips about $40^{\circ}$ to the west.

reprecipitation aided by the infiltration of illitic clay, which serves to promote dissolution between quartz grains. Hence, the possibility should be left open that the shear band permeability in the Huldra Field may at least locally be lower than those observed in shallower reservoirs.

Darker deformation bands (Fig. 11(b)) occur in sandstones where the phyllosilicate content exceeds $\sim 15 \%$. The deformation induced mixing of phyllosilicate minerals with framework grains, combined with quartz dissolution at contact points has caused a reduction in porosity and permeability. Hydraulic conductivity testing of core plugs extracted from Huldra cores (Fisher, Bolton, Vondliffe, \& White, 2001) implies a reduction in permeability of more than two orders of magnitude as compared to their host rocks.

Evidence for smearing of clay and coal layers along faults surfaces is found in one of the Huldra cores. 
The coal-bearing layer in the hanging wall of a smallscale slip surface (Fig. 11(c)) shows rotation and thinning close to the fault surface. This particular fault is also the only subseismic fault structure identified in the limited core material extracted from the Huldra reservoir. Its displacement is unknown, possibly a few meters. Interestingly, the fault separates cemented sand from uncemented sand, indicating its role as a lateral barrier to fluid flow during cementation.

\subsection{Deformation band frequency}

The limited core data indicate that most deformation bands occur in clusters of up to $\sim 25$ bands/m (Fig. 12). This is consistent with the findings from a more extensive core
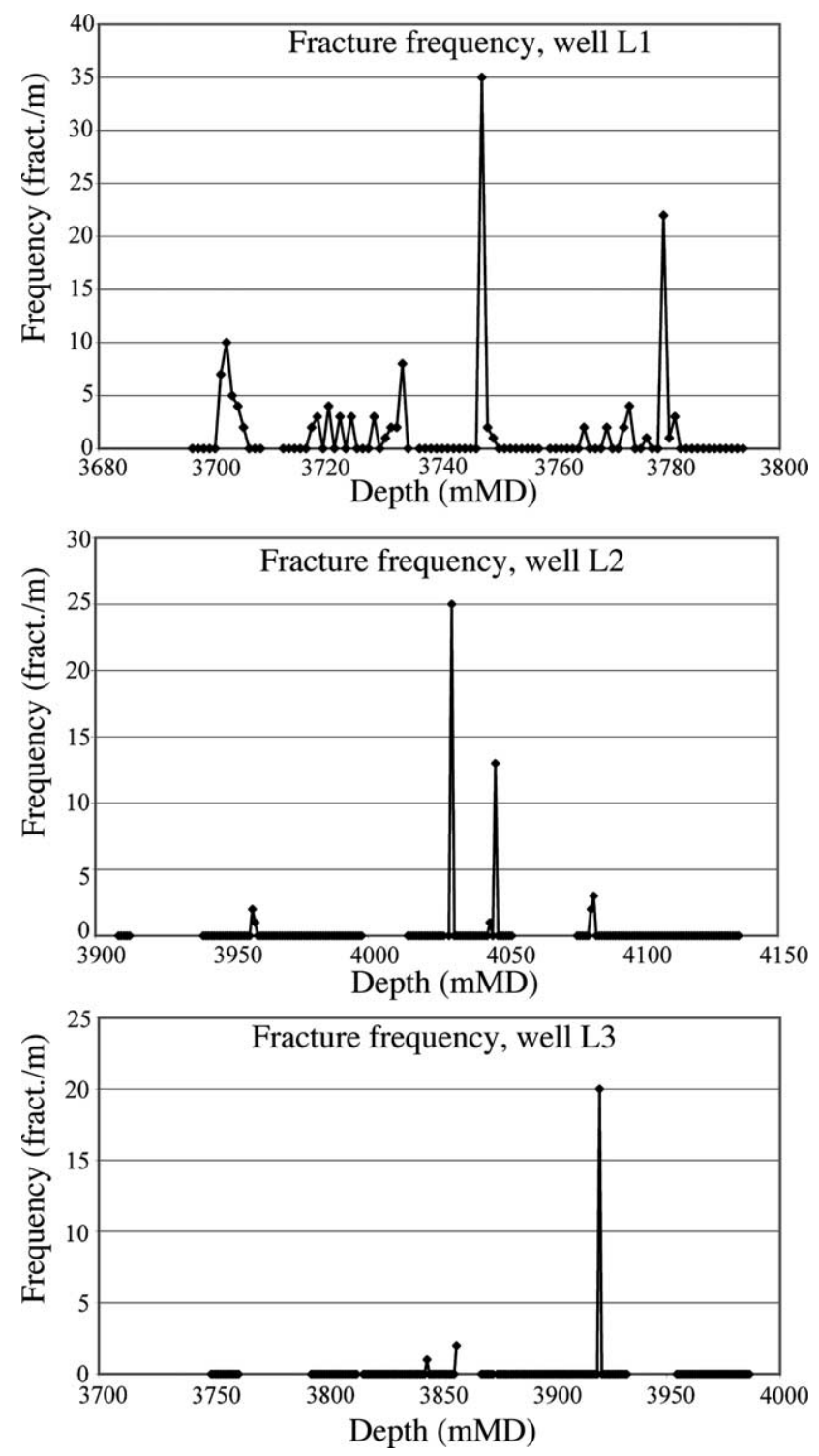

Fig. 12. Fracture frequency plots from wells L1 to L3. Most of the deformation bands are clustered in zones. These zones may be regarded as precursors to fault locations. study from the Gullfaks Field, where more than $70 \%$ of the bands occur in narrow cluster zones (Hesthammer \& Fossen, 2001). As such, deformation band zones are potentially more 'dangerous' than single bands, because cluster zones tend to form more persistent and connected barriers to fluid flow in a reservoir sandstone. Current understanding of fault growth in porous sandstones implies that they form from single bands through swarms of deformation bands until an actual fault surface forms within or along the swarm (Aydin \& Johnson, 1978; Fossen \& Hesthammer, 1998b; Shipton \& Cowie, 2001). A deformation band swarm may reveal the close proximity of an unidentified fault surface, the tip or process zone of a near-by fault, or may simply represent a precursor of a fault that never formed. Hence, the orientation of the deformation bands in the zone may somehow reflect the orientation of faults in the reservoir.

\subsection{Deformation band orientations}

The geographic orientations of some of the deformation bands encountered in the cores have been reconstructed by means of the method outlined by Hesthammer (1999). Most orientation data were obtained from well L1. The data obtained from this well show a wide range in orientations, but the majority of the deformation structures seem to have a NNW strike, with average dips in the order of $40-50^{\circ}$ to the east and west (Fig. 13). Independent field data indicate that, although deformation band orientation may be complex in a fault damage zone, the strike of the most pronounced set(s) of deformation bands tend to parallel that of the associated fault. The dip may, however, be more variable.

The average NNW trend of deformation bands in well L-1 is identical to that exhibited by major portions of faults F2 and F5 (Fig. 4). Pressure data from production wells P6 and P5 show unexpectedly poor communication that must be explained by a barrier between the two wells. A fault or well-developed deformation band swarm with a NNW orientation, i.e. parallel to the one observed in well L1 (Fig. 11(c)) could explain this lack of communication.

\section{Evolution of the Huldra fault block}

\subsection{Controlling boundary conditions}

The east-dipping Jurassic and Triassic beds in the Huldra fault block contrast strongly to the sub-horizontal layers in the Brage Horst (Veslefrikk Field) to the east (Fig. 2). This contrast is closely connected with the listric geometry of the Huldra fault. For geometric reasons, listric faults cause rotation (usually associated with internal deformation) of their hanging wall beds (e.g. Gibbs, 1983), and the Huldra fault block is a classical example of hanging-wall rotation above a listric fault. The geometry of the Huldra fault thus poses an important boundary condition on the deformation of the Huldra fault block. 

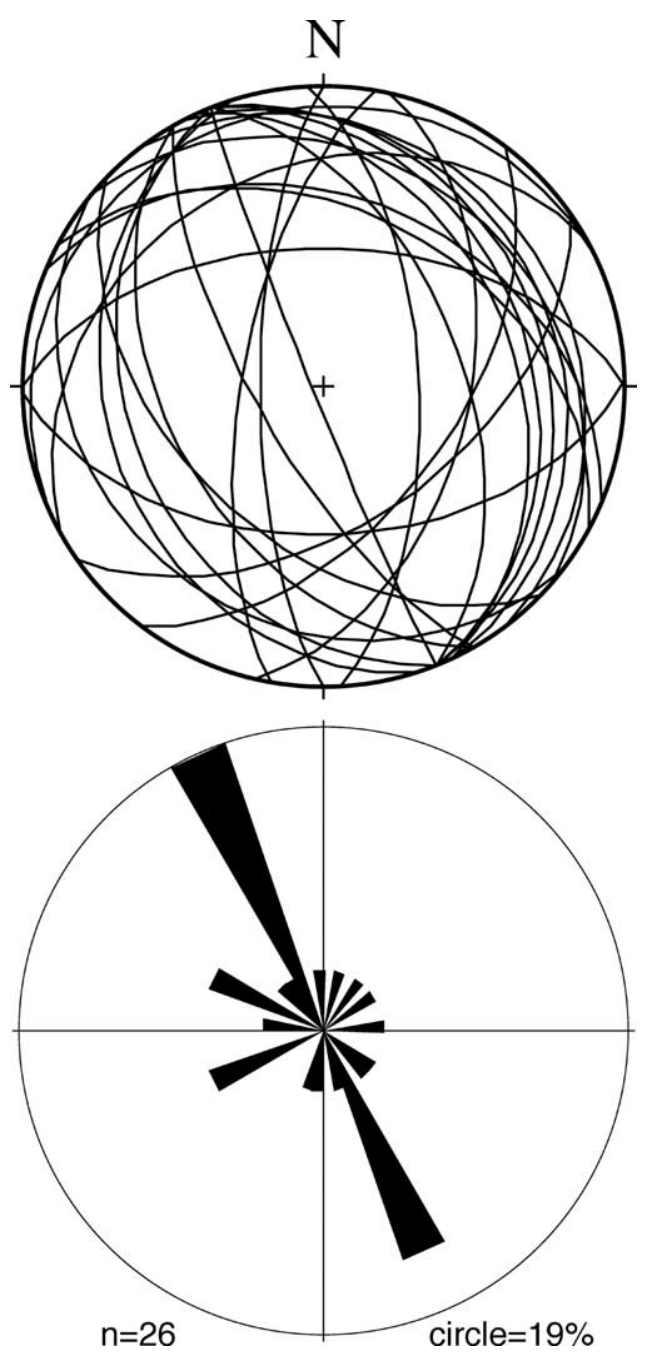

Fig. 13. Orientation of deformation bands from well L1, presented as great circles and in a rose diagram, shows that the preferred strike is to the NNW. The orientation data are based on the assumption that the cores are sliced in the dip direction of the bedding.

In simple terms, the deformation of the hanging wall over a curved fault is controlled by the geometry of the fault. If the footwall is fixed so that the geometry and orientation of the main fault is constant throughout the course of the deformation, the relationship between fault geometry and hanging-wall geometry is simple (Gibbs, 1983). Complicating factors include compactional effects and uncertainties related to depth conversion. Some considerations are presented in the following.

Plaster, clay and sand models alike indicate antithetic shear to be the most common hanging wall deformation type in simple settings (Ellis \& McClay, 1988; Matos, 1993; Odinsen, 2001; Withjack, Islam, \& La Pointe, 1995; White, Jackson, \& McKenzie, 1986) (Figs. 14 and 15), although synthetic shear has also been invoked in some cases (Fossen \& Hesthammer, 1998a; Matos, 1993; Xiao \& Suppe, 1992). It has been claimed that the orientation of minor faults in a deformed hanging wall indicates the shear direction (antithetic or synthetic). Block-internal faults in the Huldra
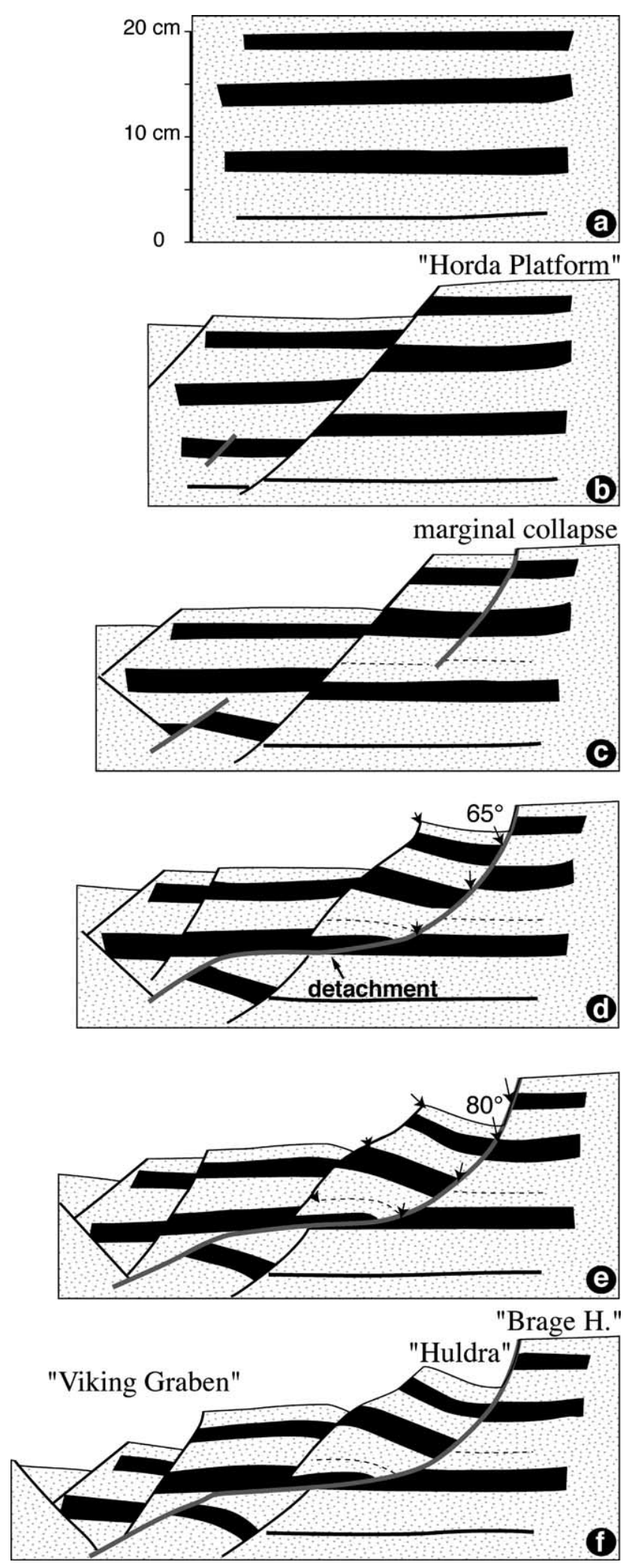

Fig. 14. Plaster experiment where early fault blocks are affected by a later curved fault with geometry similar to that of the Huldra fault. Note the rotation of the hanging-wall block (corresponding to the Huldra block). Arrows indicate steep antithetic shear (calculated). North Sea names added for structural correlation only. Modified from Fossen et al. (2000) 

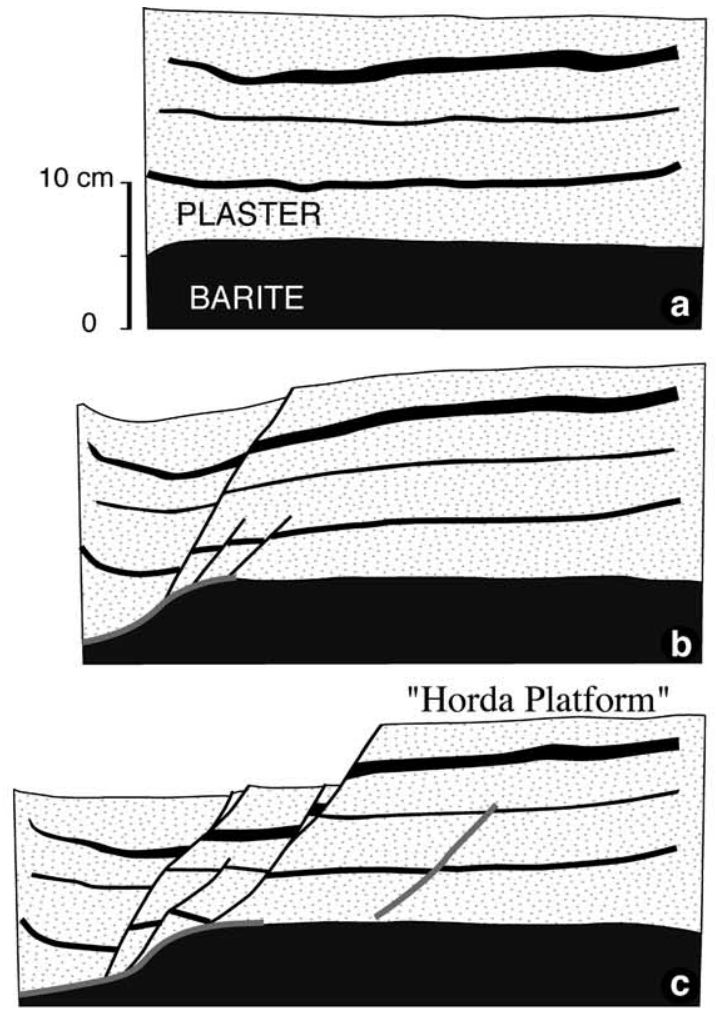

Collapsing margin
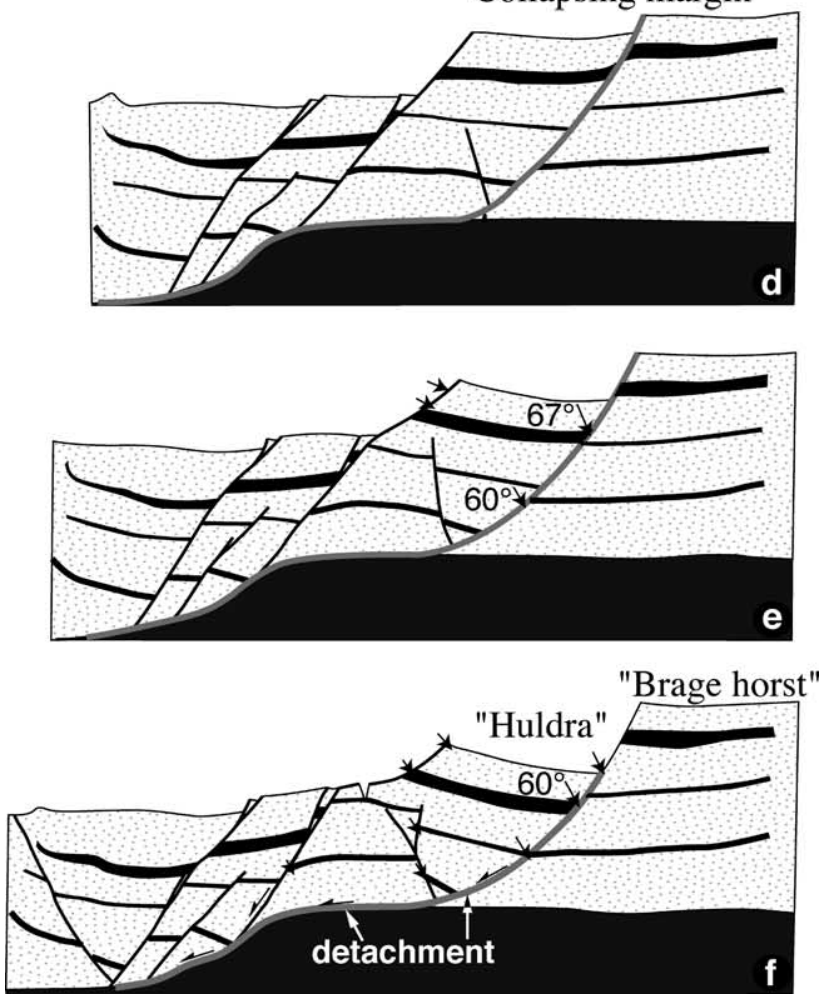

Fig. 15. Plaster experiment where a non-planar fault (representing the Huldra Fault) causes rotation of its hanging-wall block through antithetic shear. Note striking similarity between the platform collapse seen here and the collapsed margin of the Horda platform in the Huldra area portrayed in Fig. 2. Hanging-wall deformation is calculated to be antithetic shear (close to $60^{\circ}$ ). Modified from Fossen and Gabrielsen (1996). block are mostly synthetic to the main faults, and should, therefore, indicate synthetic shear. On the other hand, examples such as those portrayed in Fig. 16 demonstrate that synthetic internal faults can be perfectly compatible with overall antithetic shear. Note that the faults in Fig. 16(b) are very similar to the block-internal faults on Huldra. Hence, synthetic faults within the Huldra fault block by no means preclude antithetic shear as a general model for the hangingwall deformation associated with slip along the Huldra Fault.

Simple geometric forward modeling (Fig. 17) shows that antithetic shear gives rise to dipping layers similar to those observed in the Huldra fault block, whereas vertical and synthetic shear produce unrealistic results. Hence, antithetic shear may be a reasonable model as a first approach for the intra-Huldra block deformation. An interesting consequence of the antithetic (and other) shear model is that it predicts that the strain related to the listric Huldra fault increases to the east (towards the Huldra fault). Hence the geometry of the Huldra fault does not impose a need for anomalously high strain in the Huldra Field reservoirs at the crest of the Huldra fault block. Besides, it was argued above that the internal faults could be slightly older (indicating E-W extension) than the listric Huldra fault (consistent with NW-SE extension), in which case there is no direct relationship between the shear angle and the dip direction of the internal faults.

A discrepancy exists between the curved geometry predicted by listric fault geometry (Fig. 17(b)) and the fairly constant dip within the Huldra fault block (Fig. 5). This could indicate that the geometry of the Huldra fault as imaged in Fig. 5(c) is not entirely correct due to depth conversion uncertainties and/or inaccurate seismic
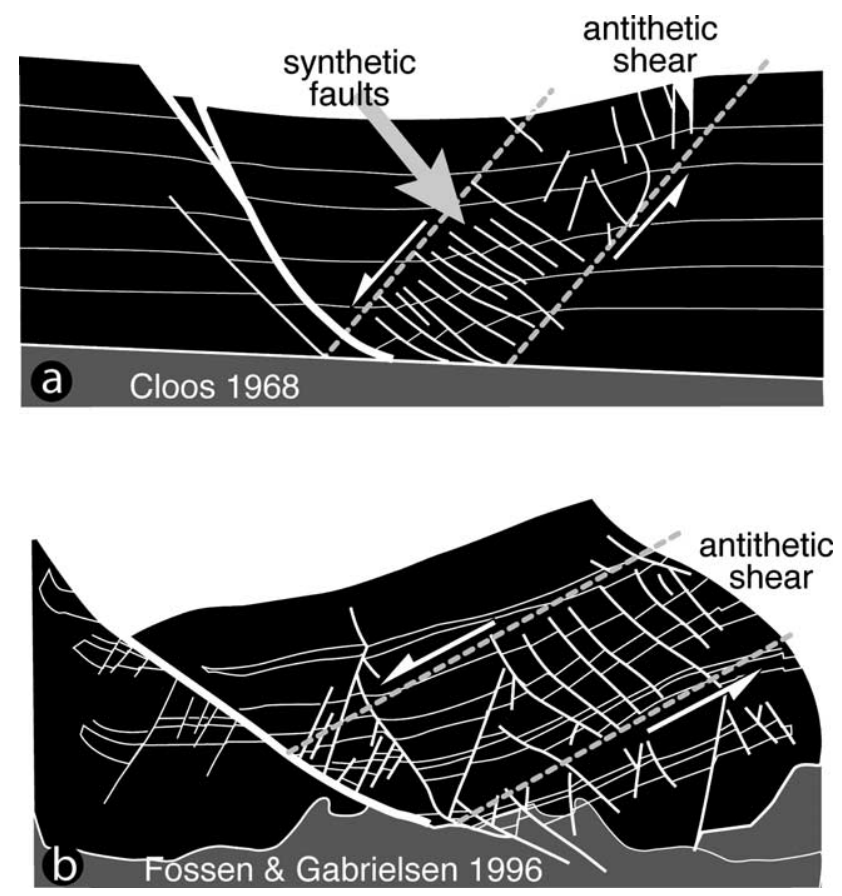

Fig. 16. Antithetic shear giving rise to synthetic faults in hanging walls to non-planar faults in (a) clay model (Cloos, 1968) and (b) plaster model (Fossen \& Gabrielsen, 1996). 

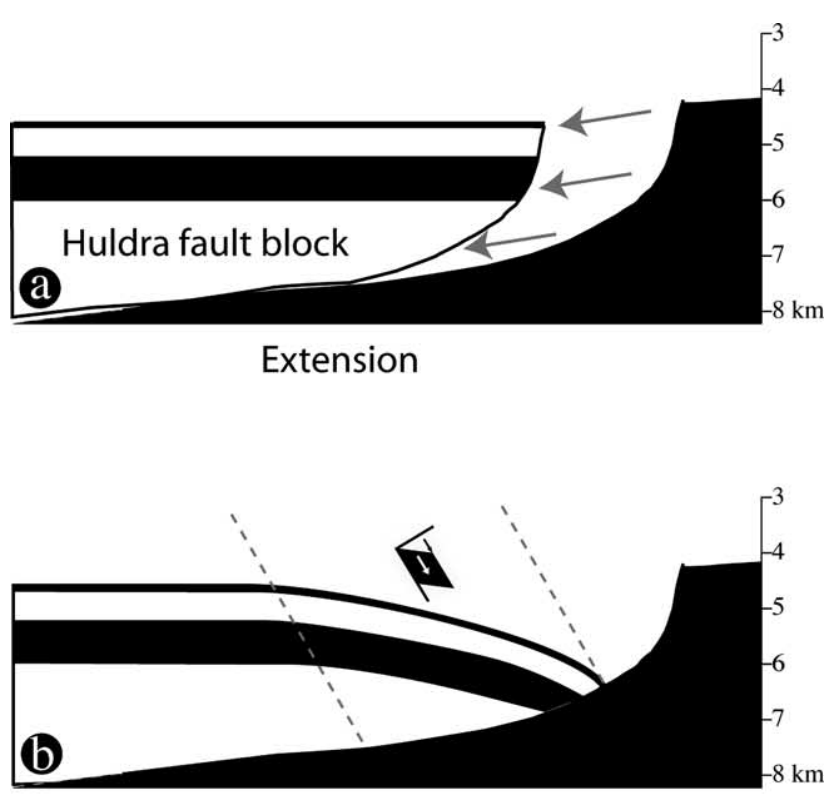

antithetic shear $\left(60^{\circ}\right)$

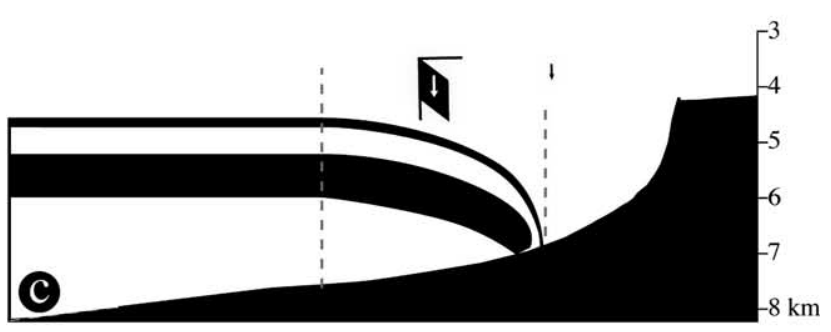

vertical shear

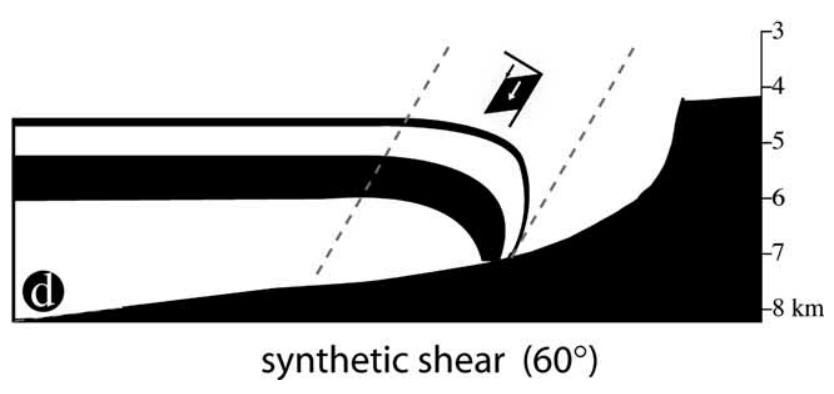

Fig. 17. Simple forward modeling of hanging wall deformation above the listric Huldra fault with a fixed footwall. A fixed amount of extension (a) creates an open space that can be filled through various modes of hanging wall collapse $(b-d)$. Antithetic shear $(b)$ provides a geometry closest to that observed at Huldra.

imaging of the fault surface. The constant dip may either indicate a homogeneous internal deformation or little internal subseismic deformation, where a large component of rigid body rotation has taken place.

\subsection{Detached platform segment}

The location of the Huldra fault block at the margin of the Horda Platform makes it likely to connect the block formation (faulting) to collapse of the platform margin. The Oseberg fault block to the south has been interpreted as such, although the collapse is more complex in that area with many more faults in a wider zone (Færseth \& Ravnås, 1998; Fig. 1). The strong influence of gravity at elevated platform margins may lead to collapse of the margin contemporaneous with regional extension and activity along the marginal fault zone (e.g. Hesthammer \& Fossen, 1999). In this sense, collapse structures are secondary structures during the evolution of rifts.

The listric geometry of the Huldra fault may be a consequence of the elevated position of the Huldra area during the middle to late Jurassic. The plaster experiments shown in Figs. 14 and 15 exemplify this point, where a rotated fault block very similar to the Huldra fault block is formed as the margin of the platform collapses. Whereas the Huldra fault block may be the first well-documented example of a rotated marginal fault block above a listric fault on the margin of the Horda Platform, several examples exist on the opposite side of the Viking Graben. The Gullfaks Sør, Visund and probably also the Gullfaks fields are all high margin areas affected by listric detachment faults that have reduced their elevation (Fossen, Odinsen, \& Færseth, 2000).

There is also a geometric necessity of a listric (non-planar) fault at the margin of the Jurassic rift system, to accommodate the rotation of fault blocks within the rift itself. This role was played by the Øygarden Fault Complex (Fig. 2) during the Permo-Triassic rifting, which extended farther to the east. As the focus of extension shifted westward during the Jurassic rifting, the Huldra fault accommodated the differential rotation across this margin of the rift system.

\subsection{Timing and extension}

The interpretation of the Huldra fault block as a marginal collapse structure implies that it is a secondary feature in the middle-late Jurassic North Sea rift system. Færseth and Ravnås (1998) presented a model where the Huldra fault block is considered being part of an Oseberg mega-fault block which existed as a unit from the Bajocian-Bathonian transition until the the Kimmeridge-Volgian.

The megablock model was developed on data from the Oseberg area south of Huldra, before the current seismic and well data from Huldra were available. Hence its relevance to the Huldra area is not clear. Well data show that the crest of the Huldra structure has Heather Formation sitting on eroded Brent sands. This implies that rotation of the Huldra fault block initiated around the Bathonian and that its crest formed an island at this time, as illustrated schematically in Fig. 18.

While erosion of the crest of the Huldra fault block could indicate growth of and rotation along the listric Huldra fault, the pre-Heather (pre-Callovian) uplift of the Huldra Field may well be a footwall uplift response to slip accumulation on the fault immediately west of Huldra. This model fits the interpretation of the Huldra fault block as a secondary structure, since the build-up of a significant gravitational 

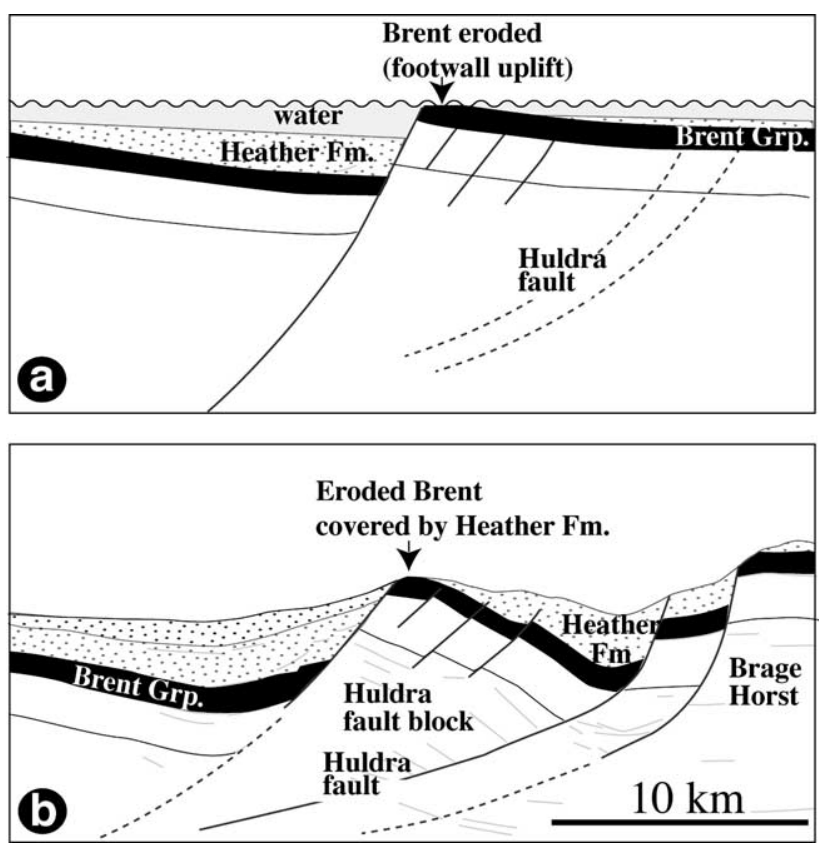

Fig. 18. The possible evolution of the Huldra-Brage area from a large-scale mega-block (a) to the post-Jurassic (and present) situation as discussed in the main text. The schematic profile is based on the Huldra-section of Fig. 2. Footwall uplift may have caused erosion of the Brent Group in the Huldra Field area (a), prior to being lowered during slip along the Huldra fault (b).

potential would require significant slip accumulation on the fault zone west of Huldra (and the Oseberg mega-faultblock). In this case its northwesterly slip (Fig. 7) confirms with the model by Færseth et al. (1997), where NW-SE extension gradually replaces $\mathrm{W}-\mathrm{E}$ extension during the late Jurassic stretching history. The largest of the internal faults in the Huldra fault block (F1) is consistent with E-W extension, which according to the model by Færseth et al. (1997) may imply that it is earlier than the Huldra fault. A package of Heather reflectors in the Huldra fault block that portray dips close to that of top Tarbert supports the view that at least the majority of the slip on the Huldra fault accumulated after deposition of the mostly Callovian Heather Formation. We envisage a model where the significant bends in the fault trace of the Huldra fault represent linked faults, similar to the model described for fault F1 (Fig. 9).

\subsection{Reservoir-size deformation structures}

One of the main concerns about the Huldra Field is the number of deformation structures at seismic and sub-sesmic scale. This study indicates that few or no major faults ( $>20 \mathrm{~m}$ offset) affect the crestal area of the structure covered by production and exploration wells. This may seem surprising, considering the fact that the crest of the structure is close to a major fault zone that runs along the western side of the Oseberg and Huldra fault blocks. However, this fault zone is more localized west of the Huldra Field than it is farther south (west of the Oseberg Field) (Fig. 1). At the same time, the elevation of the Huldra
Field was lowered through the growth of the Huldra fault (Fig. 18), reducing the gravity potential causing crestal collapse in some other North Sea fault blocks (e.g. Hesthammer \& Fossen, 1999). Hence, the Huldra Field appears to be one of several examples where the footwall is less deformed than the hanging wall.

As documented above, deformation bands and subseismic faults do exist and should be considered during reservoir management. The amount of core material available is too small to evaluate fracture frequency, although it seems comparable to what is seen in similar reservoirs, e.g. the Gullfaks Field (Hesthammer \& Fossen, 2001). Similar to the Gullfaks Field, most deformation bands occur in zones, probably associated with faults or as fault precursors. As such, they contribute to the reduction of flow across faults caused by the fault core itself (e.g. through clay smear), particularly where quartz precipitation has occurred. However, extensive compartmentalization of the reservoir by zones of deformation bands seems unlikely based on the current production data and from experience from other Brent reservoirs in the area.

\section{Conclusions}

- The Huldra fault block is bounded and geometrically controlled by the listric nature of the Huldra Fault to the east, thus representing a rotated terrace fault block similar to Visund, Gullfaks Sør and Gullfaks.

- Formation of the Huldra fault and rotation of the Huldra fault block are likely the result of gravity-influenced collapse of this portion of the Horda Platform margin. Hence, the fault block is a secondary structure in the middle to late Jurassic rifting history.

- Fault analysis indicates E-W extension within the Huldra fault block. However, the main Huldra fault is compatible with the NW-directed transport, which is consistent with a relatively late (post-Callovian) age.

- Transport of the Huldra fault block along this listric detachment has set up strain in the Huldra block that is higher than in the Brage Horst/Horda Platform to the east. Nevertheless, the deformation within the Huldra Field (crest of the fault block) is not excessive.

- Some of the mapped faults show trend variations that may be related to growth through a history of fault linkage. These locations may be hard links that contain structural complexities in the form of wide zones and high numbers of minor faults and deformation bands.

- The deformation bands studied do not involve significant cataclasis, and are expected to have a moderate influence on fluid flow during production. Deformation bands occur in zones of up to $35 / \mathrm{m}$. Most zones are thought related to faults or are precursors to faults. 


\section{Acknowledgements}

The authors thank Statoil, TotalFinaElf, ConocoPhillips, Paladin, Svenska Petroleum and Petoro for permission to publish this article. John Williams is thanked for constructive and useful comments on an earlier version of this paper, and Elisabeth Lepsøe for taking part in the seismic interpretation part of the project.

\section{References}

Aydin, A., \& Johnson, A. M. (1978). Development of faults as zones of deformation bands and as slip surfaces in sandstones. Pure and Applied Geophysics, 116, 931-942.

Badley, M. E., Egeberg, T., \& Nipen, O. (1984). Development of rift basins illustrated by the structural evolution of the Oseberg feature, block 30/6, offshore Norway. Journal of the Geological Society, 141, 639-649.

Cloos, E. (1968). Experimental analysis of Gulf Coast fracture patterns. American Association of Petroleum Geologists Bulletin, 52, 420-441.

Ellis, P. G., \& McClay, K. R. (1988). Listric extensional fault systemsresults of analogue model experiments. Basin Research, 1, 55-70.

Fisher, Q. J., Bolton, A., Vondliffe, D., \& White, E. (2001). Faulting and fault sealing in the Huldra Field. Rock Deformation Research report 2028

Fossen, H., \& Gabrielsen, R. H. (1996). Experimental modeling of extensional fault systems by use of plaster. Journal of Structural Geology, 18, 673-687.

Fossen, H., \& Hesthammer, J. (1998a). Structural geology of the Gullfaks Field, northern North Sea. In M. P. Coward, H. Johnson, \& T. S. Daltaban (Eds.), Structural geology in reservoir characterization (pp. 231-261). Special Publications, 127, London: Geological Society.

Fossen, H., \& Hesthammer, J. (1998b). Deformation bands and their significance in porous sandstone reservoirs. First Break, January.

Fossen, H., Odinsen, T., Færseth, R. B., \& Gabrielsen, R. H. (2000). Detachments and low-angle faults in the northern North Sea rift system. In A. Nøttvedt (Ed.), Dynamics of the Norwegian margins (pp. 105-131). Special Publications, 167, London: Geological Society.

Færseth, R. B., Gabrielsen, R. H., \& Hurich, C. A. (1995). Influence of basement in structuring of the North Sea basin, offshore southwest Norway. Norsk Geologisk Tidsskrift, 75, 105-119.

Færseth, R. B., Knudsen, B.-E., Liljedahl, T., Midbøe, P. S., \& Søderstrøm, B. (1997). Oblique rifting and sequential faulting in the Jurassic development of the northern North Sea. Journal of Structural Geology, 19, 1285-1302.

Færseth, R. B., \& Ravnås, R. (1998). Evolution of the Oseberg Fault-Block in context of the northern North Sea structural framework. Marine and Petroleum Geoology, 15, 467-490.

Gabrielsen, R. H., Fœrseth, R. B., Steel, R. J., Idil, S., \& Kløvjan, O. S. (1990). Architectural styles of basin fill in the northern Viking Graben. In D. J. Blundell, \& A. D. Gibbs (Eds.), Tectonic evolution of the North Sea rifts (pp. 158-183). Oxford: Clarendon Press.

Gibbs, A. D. (1983). Balanced cross-section construction from seismic sections in areas of extensional tectonics. Journal of Structural Geology, 5, 153-160

Hesthammer, J. (1998). Evaluation of the timedip, correlation and coherence maps for structural interpretation of seismic data. First Break, 16, 151-167.

Hesthammer, J (1999). Analysis of fault geometry and internal fault block deformation in the Gullfaks region, northern North Sea. Dr. Scient. Thesis. University of Bergen.

Hesthammer, J., Bjørkum, P. A., \& Watts, L. I. (2002). The effect of temperature on sealing capacity of faults in sandstone reservoirs.
American Association of Petroleum Geologists Bulletin, 86, $1733-1751$

Hesthammer, J., \& Fossen, H. (1997a). The influence of seismic noise in structural interpretation of seismic attribute maps. First Break, 15, 209-219.

Hesthammer, J., \& Fossen, H. (1997b). Seismic attribute mapping for structural interpretation of the Gullfaks Field, northern North Sea. Petroleum Geoscience, 3, 13-26.

Hesthammer, J., \& Fossen, H. (1999). Gravity collapse structures in rift settings with emphasis on the Statfjord Field, North Sea. Marine and Petroleum Geology, 16, 259-281.

Hesthammer, J., \& Fossen, H. (2001). Structural core analysis from the Gullfaks area, northern North Sea. Marine and Petroleum Geology, 18, 411-439.

Hesthammer, J., Landrø, M., \& Fossen, H. (2001). Use and abuse of seismic data in reservoir characterisation. Marine and Petroleum Geology, 18 , $635-655$.

Mansfield, C., \& Cartwright, J. A. (2001). Fault growth by linkage: observations and implications from analogue models. Journal of Structural Geology, 23, 745-763.

Matos, R. M. D. d. (1993). Geometry of the hanging wall above a system of listric normal faults-a numerical solution. American Association of Petroleum Geologists Bulletin, 77, 1839-1859.

Odinsen, T (2001). A structural model for the northern North Sea basin with particular weight on the deep structures and their impact on the development of the Mesozoic basins. Dr. Scient. Thesis. University of Bergen.

Roberts, A. M., Yielding, G., \& Badley, M. E. (1990). A kinematic model for the orthogonal opening of the late Jurassic North Sea rift system. Denmark-Mid Norway. In D. J. Blundell, \& A. D. Gibbs (Eds.), Tectonic evolution of the North Sea Rifts (pp. 180-199). Oxford: Clarendon Press.

Roberts, A. M., Yielding, G., Kusznir, N. J., Walker, I. M., \& Dorn-Lopez, D. (1993). Mesozoic extension in the North Sea: constraints from flexural back stripping, forward modeling and fault populations. In J. R. Parker (Ed.), Petroleum Geology of Northwest Europe (pp. 1123-1136). Proceedings of the Fourth Conference, Geological Society, London.

Rouby, F., Fossen, H., \& Cobbold, P. (1996). Extension, displacement, and block rotation in the larger Gullfaks area, northern North Sea: determined from map view restoration. American Association of Petroleum Geologists Bulletin, 80, 875-890.

Rykkelid, E., \& Fossen, H. (2002). Layer rotation around vertical fault overlap zones: observations from seismic data, field examples, and physical experiments. Marine and Petroleum Geology, 19, 181-192.

Scholtz, C., Dawers, N. H., Yu, J. Z., \& Anders, M. H. (1993). Fault growth and fault scaling laws: preliminary results. Journal of Geophysical Research, 98, 21951-21961.

Shipton, Z. K., \& Cowie, P. A. (2001). Damage zone and slip-surface evolution over $\mathrm{mm}$ to $\mathrm{km}$ scales in high-porosity Navaho sandstone, Utah. Journal of Structural Geology, 23, 1825-1844.

Steel, R., \& Ryseth, A. (1990). The Triassic-Early Jurassic succession in the northern North Sea: megasequence stratigraphy and intra-Triassic tectonics. In R. F. P. Hardman, \& J. Brooks (Eds.), Tectonic events responsible for Britain's oil and gas reserves (pp. 139-168). Special Publication 55, London: Geological Society.

Trudgill, B., \& Cartwright, J. (1994). Relay-ramp forms and normal-fault linkages, Canyonland National Park, Utah. Geological Society of America Bulletin, 106, 1143-1157.

White, N. J., Jackson, J. A., \& McKenzie, D. P. (1986). The relationship between the geometry of normal faults and that of the sedimentary layers in the hanging walls. Journal of Structural Geology, 8, 897-909.

Withjack, M. O., Islam, Q. T., \& La Pointe, P. R. (1995). Normal faults and their hanging-wall deformation: an experimental study. American Association of Petroleum Geologists Bulletin, 79, 1-18.

Xiao, H.-B., \& Suppe, J. (1992). Origin of rollover. American Association of Petroleum Geologists Bulletin, 76, 509-529. 